\title{
Pengaruh servant leadership learning dengan concept mapping terhadap pemahaman konsep dan berpikir kritis siswa
}

\author{
Robertus Arifin Nugroho ${ }^{1}$ *, I Gusti Putu Suryadarma ${ }^{2}$ \\ ${ }^{1}$ SMA Kolese De Britto Yogyakarta. Jalan Laksda Adisucipto No.161, Yogyakarta, 55281, Indonesia \\ ${ }^{2}$ Universitas Negeri Yogyakarta. Jalan Colombo No. 1, Yogyakarta, 55281, Indonesia \\ * Corresponding Author. Email: ipintop@yahoo.com \\ Received: 24 June 2016; Revised: 14 September 2018; Accepted: 7 November 2018
}

\begin{abstract}
Abstrak
Salah satu tujuan pendidikan nasional adalah menjadikan siswa sebagai warga negara yang bertanggung jawab. Siswa memerlukan kecakapan berinteraksi dalam masyarakat. Kecakapan tersebut adalah kemampuan memahami suatu konsep dan berpikir kritis. Penelitian ini bertujuan mengetahui pengaruh model pembelajaran Servant Leadership Learning dengan strategi Concept Mapping (SLL+CM) terhadap kemampuan pemahaman konsep dan berpikir kritis siswa kelas X SMA Kolese De Britto Yogyakarta. Penelitian ini merupakan eksperimen semu dengan desain nonequivalent subject, control group-pretest posttest design. Pendekatan ini menggunakan tiga kelas eksperimen, yaitu kelas SLL+CM, kelas SLL, kelas CM, dan satu kelas kontrol menggunakan model ceramah. Populasi infinite siswa kelas X yang terbagi dalam 7 kelas. Sampel menggunakan 4 kelas dengan penarikan sampling teknik samples of convenience. Sungai Gajah Wong digunakan sebagai objek pembelajaran. Instrumen yang digunakan bebentuk tes, kuesioner, dan observasi. Untuk menguji pengaruh model pembelajaran digunakan uji Analysis of Covariance (ANCOVA) dengan asumsi dasar normalitas, homogenitas, dan regresi. Hasil penelitian menunjukkan bahwa model pembelajaran SLL+CM memiliki pengaruh signifikan terhadap kemampuan pemahaman konsep dan berpikir kritis siswa.
\end{abstract}

Kata Kunci, metode pembelajaran Servant Leadership Learning, Concept Mapping, pemahaman konsep, berpikir kritis

\section{The effect of the servant leadership learning with concept mapping on the concept understanding and critical thinking students}

\begin{abstract}
One of the goals of national education is to make students responsible citizens. Students need skills to interact in society. These skills are the ability to understand a concept and think critically. This study aimed to find out the effect of the Servant Leadership Learning model with the Concept Mapping strategy $(S L L+C M)$ on the concept understanding and critical thinking skill of Grade $X$ students of SMA Kolese De Britto Yogyakarta. This was a quasi-experimental study using the nonequivalent subject, control group-pretest posttest design. This approach involved three experimental classes, namely the SLL+CM class, SLL class, and CM class, and one control class using the convenience approach. Gajah Wong river was used as a learning object. Population infinite all Grade $X$ students in seven classes. The research sample, consisting of four classes, was samples convenience. The instruments used were tests, questionnaires, and observations. To test the effect of the learning models, the Analysis of Covariance (ANCOVA) with normality, homogenity, and regression asumptions. The results of the study was $S L L+C M$ had significant effect on the concept understanding and critical thinking skill students.

Keywords: servant leadership learning method, concept mapping, concept understanding, critical thinking

How to Cite: Nugroho, R., \& Suryadarma, I. (2018). Pengaruh servant leadership learning dengan concept mapping terhadap pemahaman konsep dan berpikir kritis siswa. Jurnal Inovasi Pendidikan IPA, 4(1), 114-127. doi:https://doi.org/10.21831/jipi.v4i1.9823
\end{abstract}

http://dx.doi.org/10.21831/jipi.v4i1.9823 


\section{Jurnal Inovasi Pendidikan IPA, 4 (1), 2018 - 115}

Robertus Arifin Nugroho, I Gusti Putu Suryadarma

\section{PENDAHULUAN}

Pendidikan didedikasikan untuk menyadarkan siswa bahwa dirinya bukan saja makhluk individu, namun juga makhluk sosial (Koesoema, 2007, p.309; Hariyono, 2008, pp.110,115-116), baik dalam keluarga, komunitas, masyarakat, maupun konteks lebih luas sebagai bagian dari warga negara.

Siswa harus dikenalkan hidup dalam masyarakat (Bradjanagara \& Kartasoebrata, 1956, pp.12-13) dengan segala tanggung jawabnya (Morin, 2005, p.120) melalui peran yang bisa diambil sesuai tingkat perkembangan psikologinya. Seperti diungkapkan Dewantara (2013, p.193), salah satu maksud pelajaran adalah membiasakan anak-anak pada pengabdian kepada masyarakatnya, yakni mencukupkan kebutuhan masyarakat yang beraneka warna. Hal ini seturut dengan Undang-Undang Nomor 20 Tahun 2003 pasal 3 yang menyebutkan bahwa salah satu tujuan pendidikan nasional adalah menjadikan siswa sebagai warga negara yang bertanggung jawab (Republik Indonesia, 2003).

Menurut Youniss dan Yates (1997) dalam Ponder, Veldt, \& Lewis-Ferrell (2011, pp.4748), ada tiga faktor yang membantu pembentukan iden-titas kewarganegaraan, yaitu peluang melakukan aksi terhadap isu-isu yang ada di masyarakat dengan berpikir kritis, berkolaborasi untuk menanggapi isu-isu tersebut, dan merefleksikan serta mendiskusikan hubungan antara yang terjadi dalam masyarakat dan apa yang sebenarnya harus terjadi.

Membiasakan interaksi siswa dalam masyarakat tidak sekadar melibatkan siswa dalam kompleksitas permasalahan di masyarakat. Siswa harus mampu mengambil peran positif sekecil apa pun itu. Hal ini membutuhkan sikap (Hariyono, 2008, pp. 14-15), keterampilan yang memadahi (Hosnan, 2014, p.2), dan bekal kemampuan berpikir tingkat tinggi (Higher Order Thinking Skills/HOTS) karena siswa harus mampu mengolah informasi, membuat generalisasi, menyelesaikan masalah nonrutin meskipun sederhana, mengambil kesimpulan data, menerangkan hubungan kausalitas, serta mengaitkan konsep dasar sains dengan kehidupan sehari-hari di masyarakat.

Alih-alih praksis pendidikan bidang sains saat ini perlu lebih diperbaiki (Prasetyo, Riyadi, Abdi, Arham, \& Imran, 2008, p.xix) untuk membangun aspek HOTS. Hasil survei Programme for International Student Assessment (PISA) dan Trends in Internasional Match and
Science Survey (TIMSS) menunjukkan bahwa sejak tahun tahun 1999 sampai 2015, peringkat siswa Indonesia belum mampu menempati posisi atas.

Mayoritas siswa kita hanya memiliki kemampuan berpikir rendah atau Lower Order Thinking Skills (LOTS). Literasi sains, yaitu proses, konten, dan aplikasi sains siswa rendah (Permanasari, 2014, pp.3, 15).

Membangun HOTS bukan instan, melainkan pembiasaan yang dilakukan terus menerus. Salah satu kemampuan HOTS adalah berpikir kritis (King, Goodson, \& Rohani, 1998, pp.37,42; Conklin, 2012, dalam Budiman \& Jailani, 2015, p.82; Stobaugh, 2013, p.69; Schraw \& Daniel, 2011, p.23). Berpikir kritis merupakan cara berpikir (Surya, 2015, pp.117119; Mattern, et.al., 2014, p.18; Schraw \& Daniel, 2011, pp.21-22; Santrock, 2014, p.9) secara logis dengan alasan efektif dan sistematis ketika membuat keputusan atau penilaian dalam rangka menyelesaikan suatu permasalahan (The Part-nership for 21st Century Skill, 2011, pp.3738; Stobaugh, 2013, pp.2-3; Surya, 2015, pp.124-125; Ennis, 2011, p.1; Jenkins, 2015, pp.228-244; Schraw \& Daniel, 2011, pp.21, 25; Santrock, 2014, p.12).

HOTS merupakan cara berpikir yang lebih tinggi daripada menghafalkan fakta, mengemukakan fakta, atau menerapkan peraturan, rumus, dan prosedur. HOTS mengharuskan kita melakukan sesuatu berdasarkan fakta. Membuat keterkaitan antarfakta, mengkategorikannya, memanipulasinya, menempatkannya pada konteks atau cara yang baru, dan mampu menerapkannya untuk mencari solusi baru terhadap sebuah permasalahan (Thomas \& Thorne, 2009). Hal ini senada dengan pendapat Onosko \& Newman (1994), HOTS berarti "nonalgoritmik" dan didefinisikan sebagai potensi penggunaan pikiran untuk menghadapi tantangan baru. "Baru" berarti aplikasi yang belum pernah dipikirkan siswa sebelumnya. Belum tentu sesuatu yang universal bersifat baru. HOTS dipahami sebagai kemampuan siswa untuk dapat menghubungkan pembelajaran dengan elemen lain di luar yang guru ajarkan untuk diasosiasikan dengannya (Brookhart, 2010).

Kemampuan ini sangat penting dimiliki dan diperlukan ketika seseorang ingin berinteraksi dan apalagi mengambil peran dalam masyarakat (Baswedan, 2016, p.6; Clark, 2015, p.5; Endel, 2011, p.13; Mattern, et.al., 2014, pp.5-10,31; Ennis, 2007, p.14; The Partnership for 21st Century Skills, 2011, p.34; Hart 
Research Associates, 2010, p.2). Pendidikan yang baik dimulai dari situasi pembelajaran yang selalu mengarahkan siswanya berpikir kritis (Bregant, 2014, p.26).

Kemampuan berpikir kritis dapat dinilai melalui hasil pembelajaran dari permasalahan nyata dan dinilai secara otentik menggunakan permasalahan yang berbeda dari yang pernah ditemukan atau diajarkan sebelumnya (Stobaugh, 2013, pp.69-70). Maka indikator penilaian yang digunakan dalam penelitian ini adalah keterampilan siswa dalam mengidentifikasi masalah, menganalisis masalah, meng-evaluasi semua aspek yang ada dalam suatu masalah dari berbagai sudut pandang, dan menarik kesimpulan berupa sebuah keputusan atau solusi suatu masalah (Schraw \& Daniel, 2011, p. 165; Stobaugh, 2013, pp.69-70; Ennis, 1993, pp.180; 2015, 2; Stein, Haynes, \& Unterstein, 2003, pp.2-3; The Partnership for 21st Century Skills, 2011, pp.37-38; Ennis, 2015, 3-12).

Kemampuan berpikir kritis, didasari dari kemampuan siswa dalam memahami konsep materi. Konsep merujuk pada seperangkat makna yang berisi keteraturan, pola hubungan antara objek dan peristiwa. Pemahaman konsep merupakan kemampuan siswa memahami dan memaknai objek, peristiwa, maupun fenomena secara utuh menggunakan konstruksi bahasa mereka sendiri (Moran \& Keeley, 2015, p.5; Chiappetta \& Koballa, 2010, p.113; Collette \& Chiappetta, 1994, p.65; Hamzah, 2008, p.11; Dahar, 2006, p.64). Kemampuan siswa dalam memahami konsep bisa diukur dengan indikator kemampuan siswa dalam pemahaman translasi, interpretasi, dan ekstrapolasi (Bloom 1979, dalam Subiyanto, 1988, p.49)

Salah satu model pembelajaran yang dapat meningkatkan HOTS siswa pada tataran berpikir kritis adalah Project Based Learning (PjBL). PjBL adalah model pembelajaran yang menggunakan proyek terukur. Dalam kegiatan ini, siswa melakukan eksplorasi, investigasi, penilaian, interpretasi, dan sintesis informasi suatu permasalahan nyata untuk memperoleh berbagai hasil belajar (Larmer, 2014, pp.2-10).

Meskipun demikian, seharusnya siswa tidak hanya dibekali dengan kemampuan berpikir kritis saja, namun juga harus diasah afeksinya sehingga interaksi siswa dengan kompleksitas permasalahan masyarakat dapat memunculkan makna, bukan sekadar aksi dan reaksi belaka. Ranah afektif yang bisa dibangun adalah sikap kepedulian. Permasalahan yang dihadapi siswa bukan lagi imajiner, melainkan masalah nyata yang mematik sikap peduli. Sikap ini dapat dibangun menggunakan salah satu model PjBL, yaitu Servant Leadership Learning (SLL). SLL terdiri dari dua komponen yaitu Servant Leadership (SLd) dan Service Learning (SLr). Menanamkan jiwa kepemimpinan menjadi salah satu strategi untuk membangun pribadi sebagai warga negara yang bertanggung jawab dan mampu mengambil peran positif. Kepemimpinan disini diartikan bukan secara politis, namun sebagai kebenaran cara berpikir seseorang. Siswa dapat diajari prinsip kepemimpinan yang membantu sikap bertanggung jawab atas kehidupannya, bekerja dengan orang lain secara efektif, dan melakukan hal yang benar meskipun tidak diperhatikan orang (Covey, 2014, p.14).

Kepemimpinan masa kini adalah kepemimpinan yang melayani (servant leadership). Melalui kepemimpinan yang melayani akan dibangun kesadaran, empati, dan penerimaan seseorang terhadap pertumbuhan komunitas maupun masyarakat (Greenleaf, 2002, pp.33, 40-41).

SLd dapat diartikan sebagai karakter kepemimpinan yang melayani (service), memberdayakan (empowerment), dan membangun visi (visioning) bersama dalam masyarakat (Greenleaf, 2002, p.27; Blanchard, 2010, pp.277-279; Monroy-Licht, Collante-Padilla, \& González-Hernandez, 2016, p.11). Dari dasar ini muncul beberapa kunci pelayanan yaitu listening, empathy, healing, dan awareness (Spears, 2005, pp.3-4).

Komponen kedua yaitu Service Learning. Komponen ini merupakan model pembelajaran yang tidak hanya sekadar kegiatan melayani masyarakat, namun melatih siswa agar mampu menghubungkan pengalaman dengan materi akademik (Elias, 2009, p.1), sehingga memperoleh kebermaknaan atau nilai sosial (Kasali, 2012, pp.23-24).

SLr merupakan kegiatan pelayanan siswa di masyarakat dalam mengatasi permasalahan nyata dan kompleks yang mereka temukan. SLr tidak hanya berbentuk kegiatan pelayanan, namun mampu memunculkan hubungan bermakna antara pelayanan dengan pembelajaran akademik melalui proses refleksi dan evaluasi. Tahapan yang dilakukan adalah investigasi, persiapan dan perencanaan, aksi, refleksi, dan demonstrasi (Kaye, 2010, p.xi,15; Berman, 2015, pp.xxi-xxv; Dominguez \& Mc Donald, 2005, p.14; Elias, 2009, pp.1-2; Facing the Future, 2005, p.3; Heffernan, 2001, pp.2-7, 9; 
Kuntjara, Palit, Arifin, Natadjaja, \& Budi, 2013, pp.7-8; National \& Community Service, 2007, p.1; Fogarty, 1997, pp.102-105; Environmental Protection Agency, 2011, p.1; Furco, 1996, p. 17).

Melalui model ini siswa akan memperoleh banyak hal positif, diantaranya adalah berkembangnya kompetensi diri dan orang lain, menanamkan jiwa melayani dan meningkatkan kepedulian peserta didik, memunculkan hubungan antara kurikulum dengan fenomena dunia nyata, jiwa kepemimpinan, kemitraan dengan komunitas, motivasi siswa, terampil dalam memecahkan masalah, berpikir kritis, berkolaborasi, serta tumbuh dalam ranah kepribadian dan profesionalitasnya (Ponder, et.al, 2011, pp. 54,64; Sedlak, et al., 2003, p.103; Berman, 2015, pp.xxvi-xxvii; Bettencourt, 2015, p.487; Lewis, 2002, p.71; Felten \& Clayton, 2011, p.77; Kaye, 2010, p.2; Nusanti, 2014, p.259; Fogarty, 1997, p.102; Kaye, 2010, p.9)

Meskipun demikian, menurut Blumenfeld, et al. (Thomas, 2000, pp.22-23) dan Hutchison (2015, p.4), PjBL memiliki kelemahan yaitu tidak optimalnya pemahaman konsep materi yang dimiliki siswa. Maka dibutuhkan modifikasi lanjut SLL melalui kombinasi dengan strategi pembelajaran Peta Konsep (Concept Mapping).

Peta konsep/CM didefinisikan sebagai strategi pembelajaran menggunakan grafis yang menunjukkan hubungan bermakna antar konsep pengetahuan dalam bentuk proposisi-proposisi yang ditemukan dari pengalaman nyata di lapangan (Novak \& Alberto, 2008, p.1; Soleimani \& Fatemeh, 2012, p.78; Chang, Sung, \& Chen, 2002, p.5; Anonim, 2012, p.7; Dahar, 2011, p.106; Stobaugh, 2013, p.128; Erasmus, 2013, p.32).

CM memampukan siswa mengkonstruksi struktur pengetahuan yang mereka peroleh secara lebih mendalam, sebagai alat evaluasi pembelajaran dan mengoreksi kesenjangan antarkonsep pengetahuan, mampu meningkatkan kemampuan berpikir kritis, menyelidiki hal-hal yang telah diketahui siswa, mempelajari cara belajar, serta dapat membangun interaksi antarsiswa secara lebih baik (Novak, 2010, p.x, Novak \& Alberto, 2008, p.2; Wilgis \& McConnell, 2008, p.119; Santiago, 2011, p.129; Harris \& Shenghua, 2015, p.210; Arends, 2008a, p.323; Ibrahim, 2014, p.12; Ratna Willis, 2011, pp.110-113; Yusuf, 2015, p.289; Wong, 2012, p.306; Erasmus, 2013, p.32; Santiago, 2011, p137). Dalam pembelajaran yang dilaku-kan di penelitian ini ada proses intelektual membangun konsep, mengaplikasikan, menganalisis, menyintesis, dan mengevaluasi berbagai informasi permasalahan lingkungan yang diperoleh dari hasil observasi, pengalaman, dan refleksi; dimana hasil proses tersebut dimanfaatkan sebagai dasar mengambil tindakan pelayanan.

Penelitian dilakukan di SMA Kolese De Britto Yogyakarta. SMA De Britto memiliki visi membentuk peserta didik menjadi pemimpin pengabdi (service) yang cakap (competence), berhati nurani benar (conscience), dan berbela rasa (compassion) dengan tagline, to be man for and with others (SMA Kolese De Britto, 2015, p.1). Meskipun demikian, di sekolah khusus siswa laki-laki ini, tidak semua materi pembelajaran diajarkan menggunakan strategi yang secara eksplisit mengarah pada pencapaian visi. SLL+CM diharapkan dapat menjadi tawaran untuk mengatasi kebuntuan tersebut.

Kompetensi Dasar tentang ekosistem di kelas X, khususnya pencemaran lingkungan, dipilih karena sesuai dengan keprihatinan masyarakat selama ini tentang lingkungan hidup. Peradaban manusia dan sistem ekologi bumi saling berbenturan, merusak, dan mengancam (Gore, 2010, p.32). Dari kompetensi ini siswa akan diperkaya dengan materi tentang ekosistem, khususnya pada materi pencemaran air, dan merekonstruksi permasalahan lingkungan hidup yang dihadapi dengan konsep-konsep ekologis.

Lingkungan Sungai Gajah Wong digunakan sebagai bahan kajian. Sungai tersebut memiliki kontur fisik yang lebih berpotensi mengalami pencemaran dibanding dua sungai besar lainnya (Sungai Code dan Winongo) yang melintas di Kota Yogyakarta (Pemerintah Kota Yogyakarta, 2012, p.8). Hal ini dapat menimbulkan kerawanan masalah sosial maupun lingkungan hidup. Situasi ini menghasilkan sebuah kesempatan bagi siswa untuk ikut peduli terhadap lingkungan.

Aktivitas siswa dilakukan secara berkelompok atau kolaborasi heterogen (Barkeley, Cross, \& Major, 2014, p.4,68). Pembelajaran kolaboratif mampu meningkatkan pemahaman bersama, produktivitas, mencari solusi, dan atau membuat sebuah proyek yang dapat meningkatkan kemampuan berpikir kritis (Bok, 2009, p.118; Maesin, Mansor, Shafie, \& Nayan, 2009, p.74; Gokhale, 1995, p.30; Yin, Abdullah, \& Alazidiyeen, pp.60-61; Fung \& Howe, 2014, p.262; Nezami, Asgari, \& Dinarvard, 2013, p.2513). 
Aktivitas siswa diambil dari pengalaman atau konteks kehidupan sehari-hari dan permasalahan nyata sehingga mampu meningkatkan kemampuan berpikir kritis dan hasil pembelajaran sains (Carvalho, et al., 2015, p.28; White, Beck, Birrenkott, Skewes, \& Layfield, 2015, p.52; Hohmann \& Grillo, 2015, p.37; Campbell, et al., 2015, p.1349; Kumara, 2004, p.89), apalagi ketika dilakukan lintas kurikulum (Suryadarma, 2014b, p.6; Kaye, 2010, pp.119121; Anderson \& Krathwohl, 2010, pp.66,78).

Aktivitas menyusun metode pemecahan masalah, merumuskan solusi, menilai solusi, dan mencari efek umpan balik (Carvalho, et al., 2015, p.29) atau proses menganalisis, menyintesis, mendeterminasi, dan menginterpretasi (Anderson, 2015, p.88) merupakan inti dari pembelajaran tersebut.

Pembelajaran melalui kepedulian lingkungan tidak hanya meningkatkan pemahaman konsep keilmuan, namun juga values, attitude, dan skills (Suryadarma, 2014a, p.5; McMillan, 2007, p.117, Nuh, 2013, p.XII). Konsep yang dikembangkan juga memadukan berbagai bentuk keterampilan yaitu keterampilan sosial, berpikir, dan isi (Kysilka, 1998, p.199; Mustafa, 2011, p.928; Atwa \& Gouda, 2014, p.3; John, 2015, p.175).

Dari paparan tersebut, penelitian ini memiliki rumusan masalah, apakah model pembelajaran Servant Leadership Learning dengan strategi Concept Mapping (SLL+CM) berpengaruh terhadap kemampuan pemahaman konsep dan berpikir kritis siswa pada materi ekosistem di kelas X SMA Kolese De Britto Yogyakarta?

Berdasarkan rumusan masalah tersebut, penelitian ini bertujuan mengetahui pengaruh SLL+CM terhadap kemampuan pemahaman konsep dan berpikir kritis siswa pada materi ekosistem di kelas X SMA Kolese De Britto Yogyakarta.

\section{METODE}

Metode penelitian yang digunakan adalah penelitian kuantitatif, yaitu eksperimen semu (quasi experiment). Penelitian jenis ini digunakan karena populasi di kelas sudah ditentukan oleh kebijakan sekolah (naturally formed intact group) sehingga tidak ada randomisasi. Desain eksperimen kuasi yang digunakan adalah nonequivalent subject, control group-pretest posttest design (Cohen, Manion, \& Morrison, 2007, pp.282-283; Denscombe, Martin, 2007, pp.5657; Ary, Jacobs, \& Razavieh., 2011, p.316; Ali
\& Asrori, 2014, pp.88-89; Sugiyono, 2014, pp.114,116).

Penelitian dilakukan di SMA Kolese De Britto, Jl. Laksda Adisucipto 161 Yogyakarta, pada Bulan Januari-Februari 2016. Populasi infinite siswa kelas $\mathrm{X}$ sebanyak 232 siswa yang terbagi dalam 7 kelas. Sampel menggunakan 4 kelas dengan penarikan sampling teknik samples of convenience. Sampel telah tersedia sehingga dapat dipilih dengan mudah sebagai dasar bagi prosedur-prosedur inferensial. Penelitian ini menggunakan sifat dasar populasi yang memiliki karakteristik sehingga sampel yang diambil dapat dianggap acak. Dari cara ini maka populasi yang digunakan merupakan populasi hipotetik (Daniel, 1989, p.4).

Teknik pengumpulan data menggunakan tes dan nontes (Nitko \& Susan, 2015, p.9; Subali, 2012, p.1). Instrumen tes pilihan ganda digunakan untuk mengetahui kemampuan pemahaman konsep dan uraian untuk berpikir kritis. Instrumen nontes berupa lembar observasi digunakan untuk melihat keterlaksanaan pembelajaran dan kemampuan mengkomunikasikan melalui presentasi. Tahap presentasi dilakukan agar siswa memperoleh dan mengasimilasikan infromasi baru, memperluas struktur konseptual, dan mengembangkan kebiasaan mendengarkan dan berpikir (Arends, 2008 a, p.263).

Uji validitas instrumen dilakukan menggunakan teknik korelasi yang meliputi construct validity, content validity, face validity, dan empiric validity. Uji validitas menggunakan formula Product Moment Pearson Correlation dengan pendekatan Classical Test Theory program QUEST yang bertujuan untuk pemenuhan criterion referenced test (Ary, et al., 2011, p.225; Sugiyono, 2014, pp.173-190; Ali \& Asrori, 2014, p.262; Arikunto, 2015, p.80; Subali, 2012, pp.107-115; Yusuf, 2015, p.58; Widoyoko, 2014, pp.139,217; Kusaeri \& Suprananto, 2012, p.79; Latan, 2014, p.84; Edi, 2012, pp.35-36; Ghozali, 2011, p.52; Azwar, 2015, pp.8,147; Subali \& Suyata, 2012, p.40).

Reliabilitas menggunakan pendekatan konsistensi internal atau reliabilitas belah dua (split half) kemudian dianalisis menggunakan formula Spearman-Brown (Spearman-Brown Propechy) atau Cronbach Alpha. Uji lanjutan sebagai pemenuhan criterion referenced test digunakan Indeks Kappa atau indeks persetujuan (agreement index) (Ali \& Asrori, 2014, p.271; Arikunto, 2015, p. 100; Ary, Jacobs, Irvine, \& Walker, 2018, pp.236, 243-244; Azwar, 2015, pp.7, 59, 98; Edi, 2012, pp.52-53; Ghozali, 
2011, pp.47-48; Latan, 2014, pp.97-102; Subali, 2012, pp. 107,117,179; Sugiyono, 2014, pp. 173,175; Kusaeri \& Suprananto, 2012, pp. 8288; Subali \& Suyata, 2012, p.47; Widoyoko, 2014, pp.140,217; Yusuf, 2015, p.59).

Penyajian data menggunakan metode kualitatif berupa analisis deskriptif dan kuantitatif berupa analisis statistik inferensial. Pengujian hipotesis dilakukan dengan menggunakan Analysis of Covariance (ANCOVA). Kriteria pengujian adalah $\mathrm{H}_{1}$ diterima jika nilai signifikansi < 0,05 . Pemenuhan asumsi dasar uji ANCOVA menggunakan uji normalitas, homo-genitas, dan regresi (Latan, 2014, pp.8, 36-37, 116, 160-161, 370; Edi, 2012, pp.61-62, 77-86; Ghozali, 2011, pp. 160,165; Sudjana, 1980, p. 270).

\section{HASIL DAN PEMBAHASAN}

\section{Pemahaman Konsep}

Dari penelitian ini diperoleh hasil bahwa kelas SLL+CM memiliki pengaruh perbedaan rata-rata yang paling tinggi dan signifikan (Tabel 1).

Dari hasil uji ANCOVA nilai pemahaman konsep, diperoleh nilai probabilitas $0,000<$ 0,05 ; sehingga terdapat perbedaan signifikan rata-rata pengaruh model pembelajaran SLL+CM terhadap kemampuan pemahaman konsep. Hal ini terjadi karena model pembelajaran ini melibatkan proses pembuatan peta konsep yang menghubungkan temuan di lapangan dengan materi ajar yang telah diperoleh. Senada dengan Richard J. Shavelson (Novak, 2010, p.x), strategi pembelajaran dengan concept mapping terbukti dapat meningkatkan dan memperdalam pemahaman konsep, dalam hal ini materi pencemaran lingkungan. Concept mapping juga merupakan salah satu cara siswa untuk mengorganisasi pikiran mereka (Stobaugh, 2013, p.128).

Peningkatan pemahaman konsep terjadi karena proses yang dilakukan siswa melibatkan tahap identifikasi definisi pencemaran lingkungan, jenis pencemaran lingkungan, sumber pencemar, dan solusi rasional yang kesemuanya harus bisa dihubungkan dengan proposisi-proposisi logis. Melalui proses ini teori-teori ilmu tentang pencemaran lingkungan yang di-miliki siswa menjadi lebih mendalam. SLL+CM yang melibatkan tahap demonstrasi/presentasi di depan guru dan teman yang lain menggunakan slide presentasi terbatas (3 slides) menggiring siswa pada tahapan translasi, interpretasi, dan ekstrapolasi konsep.

\section{Kemampuan Berpikir Kritis}

Dari hasil penelitian tampak bahwa kemampuan berpikir kritis dapat ditingkatkan menggunakan model pembelajaran SLL+CM (Tabel 2). Dari hasil uji ANCOVA diperoleh nilai probabilitas $0,000<0,05$; sehingga terdapat perbedaan signifikan rata-rata pengaruh model pembelajaran SLL+CM terhadap kemampuan berpikir kritis.

Di kelas ini siswa mendapat pengalaman melihat langsung permasalahan di lapangan. Siswa diberi kesempatan menganalisis permasalahan tersebut dari berbagai sumber referensi (masyarakat setempat, para ahli yang kompeten, buku, dan internet). Berbagai referensi tersebut dihubungkan dengan teori-teori ekosistem yang telah dipelajari sebelumnya. Siswa lebih mampu memberi jawaban yang tepat dari berbagai indikator berpikir kritis yang terdapat di dalam soal tes, yaitu (1) siswa dapat membedakan antara akar dan bukan akar permasalahan pencemaran lingkungan, (2) siswa dapat menilai informasi yang relevan maupun tidak relevan, (3) siswa dapat memahami persoalan lingkungan sebagai dasar mengajukan pertanyaan investigatif dan rancangan penelitian, (4) siswa dapat menyusun kesimpulan atau solusi yang tepat berdasarkan argumen yang dikonstruksi dari berbagai sumber informasi.

Tabe1. Deskripsi Nilai Pemahaman Konsep

\begin{tabular}{lcccccccc}
\hline \multirow{2}{*}{ Deskripsi } & \multicolumn{8}{c}{ Kelas } \\
\cline { 2 - 9 } & \multicolumn{2}{c}{ SLL+CM } & \multicolumn{2}{c}{ SLL } & \multicolumn{2}{c}{ CM } & \multicolumn{2}{c}{ Ceramah } \\
\cline { 2 - 9 } & Pretest & Posttest & Pretest & Posttest & Pretest & Posttest & Pretest & Posttest \\
\hline Rata-rata & 61,49 & 84,88 & 52,84 & 70,27 & 66,46 & 76,25 & 53,52 & 76,25 \\
Simpangan Baku & 17,54 & 9,92 & 14,75 & 14,24 & 12,76 & 10,56 & 14,10 & 10,56 \\
Nilai Maksimal & 100,00 & 93,75 & 87,50 & 100,00 & 87,50 & 93,75 & 81,25 & 93,75 \\
Nilai Minimal & 31,25 & 62,50 & 25,00 & 25,00 & 37,50 & 50,00 & 18,75 & 50,00 \\
\hline
\end{tabular}


Jurnal Inovasi Pendidikan IPA, 4 (1), 2018 - 120

Robertus Arifin Nugroho, I Gusti Putu Suryadarma

Tabel 2. Deskripsi Nilai Kemampuan Berpikir Kritis

\begin{tabular}{lcccccccc}
\hline \multirow{2}{*}{ Deskripsi } & \multicolumn{9}{c}{ Kelas } \\
\cline { 2 - 9 } & \multicolumn{2}{c}{ SLL+CM } & \multicolumn{2}{c}{ SLL } & \multicolumn{2}{c}{ CM } & \multicolumn{2}{c}{ Ceramah } \\
\cline { 2 - 9 } & Pretest & Posttest & Pretest & Posttest & Pretest & Posttest & Pretest & Posttest \\
\hline Rata-rata & 35,75 & 77,02 & 54,29 & 65,91 & 55,00 & 69,86 & 42,97 & 61,98 \\
Simpangan Baku & 18,41 & 12,12 & 15,33 & 11,10 & 21,29 & 15,11 & 18,47 & 14,46 \\
Nilai Maksimal & 75,00 & 100,00 & 91,67 & 87,50 & 100,00 & 87,50 & 75,00 & 91,67 \\
Nilai Minimal & 8,33 & 54,17 & 25,00 & 41,67 & 16,67 & 29,17 & 8,33 & 37,50 \\
\hline
\end{tabular}

Hasil penelitian ini sesuai dengan pendapat Stobaugh (2013, pp.69-70) yang mengungkapkan bahwa skenario pembelajaran menggunakan permasalahan di dunia nyata akan memberikan kesempatan kepada siswa mencapai HOTS, yaitu berpikir kritis. Selain itu, model pembelajaran ini, sesuai dengan teori Thomas dan Thorne (2009), siswa mampu membuat keterkaitan antarfakta, mengkategorikannya, memanipulasinya, menempatkannya pada konteks atau cara yang baru, dan mampu menerapkannya untuk mencari solusi baru terhadap sebuah permasalahan, yaitu pencemaran di Sungai Gajah Wong. Siswa juga berpikir nonalgoritmik karena menghadapi tantangan baru, senada dengan pendapat Onosko \& Newman (1994) tentang strategi HOTS. Pendapat Brookhart (2010) juga terbukti karena siswa mampu menghubungkan pembelajaran ekologi dengan elemen lain di luar yang guru ajarkan untuk diasosiasikan dengannya.

Dari analisis skor presentasi kelas SLL+CM mendominasi kelas-kelas yang lain seperti tampak pada Tabel 3.

Tabel 3. Rata-rata Skor Presentasi untuk Mengukur Kemampuan Berpikir Kritis

\begin{tabular}{cccccc}
\hline \multirow{2}{*}{ Kelas } & \multicolumn{4}{c}{ Indikator } & \multirow{2}{*}{ Rata-rata } \\
\cline { 2 - 5 } & $\mathbf{1}$ & $\mathbf{2}$ & $\mathbf{3}$ & $\mathbf{4}$ & \\
\hline SLL+CM & 2,88 & 2,67 & 2,79 & 2,54 & 2,72 \\
SLL & 2,71 & 2,04 & 2,04 & 2,17 & 2,24 \\
CM & 2,38 & 2,08 & 1,96 & 1,58 & 2,00 \\
Ceramah & 2,21 & 1,42 & 1,42 & 0,96 & 1,50 \\
\hline
\end{tabular}

Skor tinggi tersebut diperoleh karena siswa kelas SLL+CM paling aktif, percaya diri, cakap dan mendalam saat memaparkan, serta mampu menunjukkan kompetensi sangat baik di semua indikator kemampuan berpikir kritis. Hal ini membuktikan bahwa mengamati permasalahan yang ada di masyarakat secara langsung dan dipadu dengan penguatan konsep keilmuannya melalui pembuatan peta konsep mampu meningkatkan kemampuan berpikir kritis siswa.

Tahapan mengobservasi pencemaran Sungai Gajah Wong mampu mengembangkan kompetensi mengidentifikasi permasalahan.
Melalui tahapan ini siswa dapat melihat dan merasakan langsung dampak pencemaran sungai. Siswa mampu membedakan antara fakta, opini, dan klaim. Sungai Gajah Wong tercemar oleh sampah merupakan suatu fakta yang ditemukan siswa. Opini yang muncul selanjutnya bahwa pencemaran oleh sampah disebabkan warga sekitar lokasi pencemaran yang membuang sampah secara sembarangan. Namun karena siswa melihat langsung keseharian warga, maka klaim yang muncul menunjukkan fakta yang lebih mendalam, yaitu bahwa warga sekitar lokasi tidak serta-merta memiliki kebiasaan membuang sampah sembarangan di sungai. Sebagian besar warga sekitar telah memiliki kesadaran karena tidak ingin sakit, tidak mau selalu mencium bau sampah, dan tidak mau menderita karena banjir akibat sampah yang menumpuk di sungai. Siswa di kelas ini menemukan bahwa warga lain di luar lokasi pencemaran ikut andil dalam permasalahan ini.

Tahapan wawancara dengan warga terdampak dan berdiskusi dengan para ahli mampu mengembangkan kemampuan menganalisis permasalahan yang dihadapi. Proses menganalisis merupakan dasar dari proses mengevaluasi dan mengkreasi solusi atau kesimpulan. Siswa mengalami tahapan differenting dan organizing. Siswa memilih kebenaran informasi dengan cara wawancara dengan warga, melihat keseharian mereka, dan melihat langsung kondisi Sungai Gajah Wong. Siswa juga melakukan pengumpulan dan pengorganisasian berbegai informasi tersebut. Kemampuan ini meningkat karena dibantu dengan strategi concept mapping yang menjelaskan multiinteraksi berbagai informasi.

Selain itu, berdiskusi dengan para ahli mampu membuka wawasan siswa bahwa pencemaran lingkungan tidak hanya berdampak pada aspek kesehatan dan ekosistem saja, melainkan juga memunculkan multidampak, misalnya hukum, sosial, dan keamanan.

Hal lain yang diperoleh dari tahapan mengobservasi adalah kemampuan mengevaluasi semua aspek dari berbagai sudut pandang. Siswa mengalami proses checking, view all 
points, dan critiquing. Melalui tahapan ini para siswa menemukan informasi yang paling berpengaruh, paling konsisten, paling berkualitas, maupun paling substansial. Siswa mampu melihat secara divergen dengan berbagai alternatif informasi. Siswa juga melalui tahap mengkritisi berbagai bukti atau informasi yang diperoleh agar bisa menjadi dasar yang tepat dalam merumuskan solusi, apalagi siswa dituntut memberikan solusi yang bersifat memberdayakan (empowering).

Kemampuan melihat secara divergen terhadap berbagai sumber informasi dilanjutkan dengan kemampuan siswa untuk berpikir secara konvergen. Dalam tahap menarik kesimpulan melalui rumusan solusi, siswa membuat sebuah solusi yang paling tepat dan mampu memberdayakan masyarakat. Tentunya solusi tersebut harus dikonstruksi berdasarkan argumen yang kuat. Jika dibandingkan dengan kelas kontrol yang tidak mendapat pengalaman langsung di lapangan, banyak terjadi kekeliruan dalam mengambil kesimpulan. Kekeliruan informal baik berupa fallacy of hasty generalization maupun fallacy of forced hypothesis (Ranjabar, 2014, pp.101-102). Kekeliruan karena membuat generalisasi yang terburu-buru terjadi akibat siswa mengambil kesimpulan umum dari kasus khusus yang terlampau sedikit. Sedangkan kekeliruan karena memaksa praduga terjadi akibat siswa membuat kesimpulan dari praduga bukan fakta yang terjadi di lapangan.

Dari tahap wawancara dengan ahli, siswa juga mengenal dan belajar berinteraksi serta berkomunikasi dengan orang lain, misalnya dosen, dokter rumah sakit, Puskesmas, Dinas Kelautan dan Perikanan, Balai Pengelolaan Daerah Aliran Sungai (BPDAS) Opak dan Serayu, Forum Komunikasi Daerah Aliran Sungai (FORSIDAS) Gajah Wong, Wahana Lingkungan Hidup (WALHI), Badan Lingkungan Hidup (BLH), dan lain-lain.

Tahapan siswa menyampaikan ide atau solusi penanganan pencemaran lingkungan kepada tokoh masyarakat, misalnya RT/RW, kadus, kades, atau tokoh agama, ternyata menjadi tantangan positif bagi siswa. Siswa tidak berani membuat solusi yang asal-asalan karena harus disampaikan kepada orang lain yang notabene tidak mereka kenal dan sangat disegani di masyarakat serta harus beradu argumen dalam memaparkan kepada orang tersebut. Solusi yang dibuat pun harus masuk akal dan dapat memberdayakan masyarakat sehingga argumen yang kuat harus menjadi bekal dalam diskusi yang dilakukan.

\section{Respon Siswa terhadap Pembelajaran}

Kelas SLL+CM memiliki skor respon terhadap pembelajaran paling tinggi dengan kategori sangat positif (Tabel 4).

Tabel 4. Jumlah Responden dan Skor Kuesioner Respon Siswa Terhadap Pembelajaran

\begin{tabular}{ccc}
\hline Kelas & Jumlah Responden & Jumlah Skor \\
\hline SLL+CM & 32 & 2384 \\
SLL & 32 & 2246 \\
CM & 33 & 2352 \\
Ceramah & 30 & 2158 \\
\hline
\end{tabular}

Siswa di kelas SLL+CM merasa senang dengan pembelajaran yang menghubungkan konsep materi dengan permasalahan nyata di lingkungan. Siswa juga merasa terasah kemampuan berpikir kritisnya. Hal ini senada dengan pendapat Ritchhart \& Perkins (2008, dalam Stobaugh, 2013, 136) yang menyatakan bahwa siswa akan lebih tertarik dalam aktivitas berpikirnya ketika mereka dapat mengoneksikannya dengan pengalaman nyata yang mereka alami.

Refleksi pembelajaran yang dilakukan siswa didasarkan pada model DEAL (Describe, Examine, and Articulate Learning) (Molee, Henry, Sessa, \& McKinney-Prupis, 2010, p.243; Odom, Shehane, Moore, \& McKim, 2014, p.216). Dari refleksi singkat siswa terlihat bahwa substansi refleksi kelas SLL+CM lebih ber-makna dan mendalam ke arah pencarian nilai (values) kehidupan dibanding kelas yang lain. Refleksi yang dibuat tidak berhenti pada tulisan, namun beberapa siswa menuliskan niat konkret yang akan dilakukan selanjutnya.

\section{SIMPULAN}

Model pembelajaran Servant Leadership Learning dengan strategi Concept Mapping (SLL+CM) berpengaruh signifikan terhadap kemampuan pemahaman konsep dan berpikir kritis siswa. SLL memberi kontribusi mengonstruksi atau mengidentifikasi permasalahan nyata yang dihadapi. Sedangkan strategi pembelajaran CM memberikan kontribusi dalam meningkatkan pemahaman dan keterkaitan konsep ilmu pengetahuan dengan permasalahan tersebut.

\section{DAFTAR PUSTAKA}

Ali, M., \& Asrori, M. (2014). Metodologi \& aplikasi riset pendidikan. Jakarta: Bumi Aksara. 
Anderson, L. W., \& Krathwohl, D. R. (2010). Kerangka landasan untuk pembelajaran, pengajaran, dan asesmen, revisi taksonomi pendidikan Bloom. (Terjemahan Agung Prihantoro). New York, NY.: Addison Wesley Longman, Inc.

Anderson, M. (2015). The case against" Critical thinking skills": In pursuit of a humanizing pedagogy. Philosophical Studies in Education, 46, 83-89.

Anonim. (2012). Concept maps are not mind maps. Owenkelly, Retrived from: www.owenkelly.net/691/concept-mapsare-not-mind-maps/.

Arends, R. (2008a). Learning to teach, belajar untuk mengajar. Ed. 7. Buku 1. (Terjemahan Helly Prajitno \& Sri Mulyantini). New York, NY.: McGraw Hill Companies, Inc.

Arends, R. (2008b). Learning to teach, belajar untuk mengajar. Ed. 7. Buku 2. (Terjemahan Helly Prajitno \& Sri Mulyantini). New York, NY.: McGraw Hill Companies, Inc.

Arikunto, S. (2015). Dasar-dasar evaluasi pendidikan. Ed.2. Jakarta: Bumi Aksara.

Ary, D., Jacobs, L. C., \& Razavieh, A. (2011). Pengantar penelitian dalam pendidikan. (Terjemahan Arif Furchan). Surabaya: Usaha Nasional.

Ary, D., Jacobs, L. C., Irvine, C. K. S., \& Walker, D. (2018). Introduction to research in education. Belmont: Cengage Learning.

Atwa, H.S. \& Gouda, E. M. (2014). Curriculum integration in medical education, A theoretical review. Intellectual Properties Rights, An Open Access Journal, 2(2).

Azwar, S. (2015). Reliabilitas dan validitas. Edisi 4. Yogyakarta: Pustaka Pelajar.

Barkeley, E. E., Cross, K. P., \& Major, C. H. (2014). Collaborative learning technique, teknik-teknik pembelajaran kolaboratif. (Terjemahan Narulita Yusron). San Fancisco, Jossey-Bass.

Baswedan, A. (2016). Revolusi mental, konsepsi tokoh-tokoh pendidikan Indonesia yang mendunia. Seminar Nasional 2016. Yogyakarta: SMK Negeri 2 Yogyakarta.

Berman, S. (2015). Service learning a guide to planning, implementing, and assessing student project. New York, NY.: Skyhorse Publishing.

Bettencourt, M. (2015). Supporting student learning outcomes through service learning. Foreign language annals, 48(3), 473-490.

Blanchard, K. H. (2010). Leading at a higher level: Blanchard on leadership and creating high performing organizations. New Jersey: FT Press.

Bok, D. (2009). Our underachieving colleges: A candid look at how much students learn and why they should be learning morenew edition (Vol. 50). New Jersey: Princeton University Press.

Bradjanagara, S. \& Kartasoebrata, L. (1956). Djalan baru untuk memperbaharui pendidikan dan pengadjaran sekolah rakjat Pantjasila.

Bregant, J. (2014). Critical thinking in education, why to avoid logical fallacies? Problems of Education in the 21st Century, 61.

Brookhart, S. M. (2010). How to assess higherorder thinking skills in your classroom. Massachusetts: ASCD

Budiman, A., \& Jailani, J. (2015). Developing an assessment instrument of higher order thinking skill (HOTS) in mathematics for junior high school grade VIII semester 1 . Proceeding of International Conference On Research, Implementation And Education Of Mathematics And Sciences 2015, Yogyakarta State University, 17-19 May 2015.

Campbell, N. A., Reece, J. B., Urry, L. A., Cain, M. L., Wasserman, S. A., Minorsky, P.V., \& Jackson, R. B. (2015). Biology, a global approach. 10th Ed. England, Pearson Education Limited.

Carvalho, C., Fíuza, E., Conboy, J., Fonseca, J., Santos, J., Gama, A. P., \& Salema, M. H. (2015). Critical thinking, real life problems and feedback in the sciences classroom. Journal of Turkish Science Education, 12(2).

Chiappetta, E.L \& Koballa, T. R. (2010). Science instruction in the middle and secondary schools. New York, NY.: Allyn \& Bacon.

Clark, H. (2015). Building a common language for career readiness and success: A 
foundational competency framework for employers and educators. ACT Working Paper Series. February 2015.

Cohen, L., Manion, L., \& Morrison, K. (2007). Research methods in education. 6th.ed. New York, NY.: Rouledge Taylor \& Francis Group.

Collette, A.T \& Chiappetta, E.L. (1994). Science instruction in the middle and secondary schools. New York, NY.: Macmillan Publishing Company.

Covey, S. (2014). The leader in me. New York, NY.: Simon and Schuster.

Dahar, R.W. (2011). Teori-teori belajar dan pembelajaran. Jakarta: Erlangga.

Daniel, W. W. (1989). Statistika nonparametrik terapan (Terjemahan Alex Tri Kantjono W). New York, NY.: Houghton Mifflin Company.

Darmawan, H. (2013). Dimensi-dimensi metode penelitian pendidikan dan sosial: Konsep dasar dan implementasi. Bandung, Penerbit Alfabeta.

Denby, A.R. (2008). The impact of service learning on students' sense of civic responsibility. Tesis. Ontario: Faculty of Education The University of Western Ontario.

Denscombe, M. (2007). The good research guide. 3rd.ed. New York, NY.: The McGraw-Hill Companies.

Dewantara, K. H. (2013). Ki Hadjar Dewantara bagian pertama, pendidikan. Cetakan ke5. Yogyakarta: UST Press \& Majelis Luhur Persatuan Tamansiswa.

Dominguez, L. \& McDonald, J. (2005). Environmental service-learning projects, Developing skills for action. Green Teacher. Toronto: Spring, Iss. 76; pg. 13, 5 pgs.

Edy, A. (2012). Aplikasi praktis SPSS dalam penelitian. Yogyakarta: Gava Media.

Elias, M. (27 Juni 2009). How to bring service learning to your school. Diambil pada tanggal 3 Jamuari 2015, dari http,//www.edutopia.org/blog/bringservice-learning-to-your-school-mauriceelias.

Endel, B. L. (2011). Breaking new ground building a national workforce skills credentialing system. ACT Working Paper Series.
Ennis, H.R. (1993). Critical thinking assessment. Ohio 1993. Theory into Practice. 32 (3).

Ennis, H.R. (2011). The nature of critical thinking, An outline of critical thinking dispositions and abilities.

Ennis, R.H. \& Eric, W. (1985). The Ennis-Weir critical thinking essay test, Test-manualcriteria-scoring sheet an instrument for teaching and testing. California: Midwest Publications.

Ennis, R.H. \& Geoffrey, S.C. (2015). An annotated list of english-language critical thinking tests. Illinois: University of Illinois.

Ennis, R.H. \& Marguerite, F. (1993). Illinois critical thinking essay test. Illinois: University of Illinois.

Ennis, R.H. (2015). The nature of critical thinking, Outlines of general critical thinking dispositions and abilities. Illinois: University of Illinois. Diambil pada tanggal 24 September 2015 pukul 13.00 WIB

dari http,//www.criticalthinking.net/longdefinit ion.html.

Ennis, T.R. (2007). Assessing and enhancing critical thinking skills, Enhanced Peer Review (EPR) with the CAT instrument. Doctoral Dissertation. Tennessee Technological University

EPA. (2011). Service-learning, learning by doing, students take greening to the community. New York, NY.: United States Environmental Protection Agency.

Erasmus, C.J. (2013). Concept mapping as a strategy to enhance learning and engage students in the classroom. Journal of Family and Consumer Sciences Education, 31(1) Spring/Summer 2013.

Facing the Future. (2005). Service learning framework, make your teaching stick and change the world, a manual for developing your own service learning project. Facing the Future.

Felten, P., \& Clayton, P.H. (2011). Servicelearning. Teaching and learning, No. 128, Winter 2011.

Fogarty, R. (1997). Problem-based learning and other curriculum models for the multiple intelligences classroom. Glenview: Sky Light Professional Development. 
Fung, D. \& Howe, C. (2014). Group work and the learning of critical thinking in the Hong Kong secondary liberal studies curriculum. Cambridge Journal of Education, 44(2), 245-270.

Furco, A. (1996). Service-learning, A balanced approach to experiential education. Expanding Boundaries: Service \& Learning. Corporation for National Service.

Ghozali, I. (2011). Aplikasi analisis multivariate dengan program IBM SPSS 19. Semarang: Badan Penerbitan Universitas Diponegoro.

Gokhale, A.A. (1995). Collaborative learning enhances critical thinking. Journal of Technology E ducation, 7, 1,22-30.

Gore, Al. (2010). Our choice, rencana untuk memecahkan krisis iklim. (Terjemahan Hardono Hadi). New York, NY.: Rodale. (Buku asli terbit tahun 2009).

Greenleaf, K.R. (2002). Servant leadership, A journey into the nature of legitimate power and greatness. New Jersey: Paulist Press.

Hamzah, B.U. (2008). Model pembelajaran. Jakarta: Bumi Aksara.

Hariyono, P. (2008). Mendongkrak kualitas pendidikan. Semarang: Mutiara Wacana.

Harris, C.M., \& Shenghua, Z. (2015). Concept mapping, a critical thinking technique. Education Journal, 134(2).

Hartini, H., \& Sukardjo, S. (2015). Pengembangan higher order thinking multiple choice test untuk mengukur keterampilan berpikir kritis IPA kelas VII SMP/MTs. Jurnal Inovasi Pendidikan IPA, $\quad$ l(1), 86-101. doi:http://dx.doi.org/10.21831/jipi.v1i1.45 35

Heffernan, K. (2001). Fundamentals of service learning course construction. RI, Campus Compact, pp2-7, 9.

Hohmann, J.W. \& Grillo, M.C. (2014). Using critical thinking rubrics to increase academic performance. Journal of College Reading and Learning, 45, 35-51, 2014.

Hosnan, M. (2014). Pendekatan saintifik dan kontekstual dalam pembelajaran abad 21. Bogor: Ghalia Indonesia.

Hutchison, David. (2015). Project basedlearning, Drawing on best practices in project management. What Work? Research into Practice. Ontario,
September 2015. Research monograph\#60.

Ibrahim, M. (2014). Asesmen autentik dalam pembelajaran sains abad 21. Seminar Nasional Pendidikan Sains Program Pascsarjana UNY. Yogyakarta: Program Pascasarjana UNY.

Jenkins, S. (2015). Tools for critical thinking in biology. New York, NY.: Oxford University Press.

John, Y.J. (2015). A "New" thematic, integrated curriculum for primary schools of Trinidad and Tobago, A paradigm shift. International Journal of Higher Education, Vol. 4, No. 3.

Kasali, R. (2012). Cracking values, bersih, bersinar, dan kompetitif. Jakarta: Gramedia Pustaka Utama.

Kaye, C. B. (2010). The complete guide to service learning, proven, practical ways to engage students in civic responsibility, academic curriculum, \& social action. Minneapolis: Free Spirit Publishing Inc.

Yin, K. Y., Abdullah, A. G. K., \& Alazidiyeen, N. J. (2011). Collaborative problem solving methods towards critical thinking. International Education Studies, 4(2), 58.

King, F. J., Goodson, L., \& Rohani, F. (1998). Higher order thinking skills: Definition, teaching strategies, assessment. Publication of the Educational Services Program, now known as the Center for Advancement of Learning and Assessment.

Koesoema, D. (2007). Pendidikan karakter, strategi mendidik anak di zaman global. Jakarta: Grasindo

Kumara, A. (2004). Model pembelajaran "Active Learning" mata pelajaran sains tingkat SD Kota Yogyakarta sebagai upaya peningkatan "Life Skills". Jurnal Psikologi, 31(2), 63-91.

Kuntjara, E., Palit, H., Arifin, L. S., Natadjaja, L., \& Budi, Y. (2013). Panduan pelaksanaan service learning di Universitas Kristen Petra. Surabaya, LPPM Universitas Kristen Petra.

Chang, K. E., Sung, Y. T., \& Chen, I. D. (2002). The effect of concept mapping to enhance text comprehension and summarization. The Journal of Experimental Education, 71(1), 5-23. 
Kusaeri, K., \& Suprananto, S. (2012). Pengukuran dan penilaian pendidikan. Yogyakarta, Graha Ilmu.

Kysilka, M.L. (1998). Understanding integrated curriculum. The Curriculum Journal, 9(2)

Larmer, J., Mergendoller, J., \& Boss, S. (2015). Setting the standar for project based learning, a proven approach to rigorous classroom instruction. ASCD.

Larmer, J. (2014). Project-based learning vs. problem-based learning vs. X-BL. Buck Institute for Education (BIE).

Latan, H. (2014). Aplikasi analisis data statistik untuk ilmu sosial sains dengan IBM SPSS. Bandung: Alfabeta.

Lewis, A. (2002). Service learning. The Education Digest; Apr 2002; 67, 8; ProQuest Professional Education, pg. 71.

Monroy-Licht, A., Collante-Padilla, A., \& González-Hernandez, R. (2016). An environmental management project: Situated learning to enhance critical thinking skills in college students. Transformative Dialogues: Teaching \& Learning Journal, 8(3), 1-13.

Maesin, A., Mansor, M., Shafie, L. A., \& Nayan, S. (2009). A study of collaborative learning among Malaysian undergraduates. Asian Social Science, 5(7), 70.

Mattern, K., Burrus, J., Camara, W., O'Connor, R., Hansen, M. A., Gambrell, J., ... \& Bobek, B. (2014). Broadening the definition of college and career readiness: A holistic approach. ACT Research Report Series, 2014 (5). ACT, Inc.

McMillan, J. H. (2007). Formative classroom assessment: Theory into practice. Teachers College Pr.

Molee, L. M., Henry, M. E., Sessa, V. I., \& McKinney-Prupis, E. R. (2011). Assessing learning in service-learning courses through critical reflection. Journal of Experiential Education, 33(3), 239-257.

Moran, K.R. \& Keeley, P. (2015). Teaching for conceptual understanding in science. Virginia: NSTA Press.

Morin, E. (2005). Tujuh materi penting bagi dunia pendidikan. (Terjemahan Imelda Kusumastuty, Hanandyo Dardjito, Ontje Helena Manurung). Paris: UNESCO.
Mustafa, J. (2011). Proposing a model for integration of social issues in school curriculum. International Journal of Academic Research, 3(1).

National \& Community Service. (2007). The impact of service learning, A review of current research. New York, NY.: Freedom Corps.

Nezami, N. R., Asgari, M., \& Dinarvand, H. (2013). The effect of cooperative learning on the critical thinking of High School students. Technical Journal of Engineering and Applied Sciences, 3(19), 2508-2514.

Nitko, A. J. \& Susan, M.B. (2015). Educational assessment of students. 7th Ed. New Jersey: Pearson Education.

Novak, J., \& Alberto J. Canas. (2008). The theory underlying concept maps \& how to construct and use them. Florida: Institute for Human and Machine Cognition.

Novak, J. (2010). Learning, creating, and using knowledge, Concept maps as facilitative tools in schools and corporations. 2nd Ed. New York, NY.: Routledge.

Nuh, M. (2013). Menyambut kurikulum 2013, Forum Mengunwijaya VII. Jakarta: Kompas.

Nusanti, I. (2014). Strategi service learning sebuah kajian untuk mengembangkan kegiatan pembelajaran. Jurnal Pendidikan dan Kebudayaan, 20(2), 251-260.

Odom, S. F., Shehane, M., Moore, L. L., \& McKim, B. (2014). An analysis of a highimpact field experience in agriculture: Documenting critical thinking skills through reflection. NACTA Journal, 58(3), 214.

Onosko, J. J., \& Newmann, F. M. (1994). Creating more thoughtful learning environment. In J. Mangieri, \& C. C. Blocks (Eds.), Creating powerful thinking in teachers and students diverse perspectives (pp. 27-49). Fort Worth, Brace College Publishers

Pemerintah Kota Yogyakarta. (2012). Buku data status lingkungan hidup daerah Kota Yogyakarta Tahun 2012. Yogyakarta: Pemerintah Kota Yogyakarta Provinsi Daerah Istimewa Yogyakarta.

Permanasari, A. (2014). Memperkokoh pendidikan melalui pembelajaran 
integratif berbasis STEM. Seminar Nasional Pendidikan Sains Program Pascsarjana UNY. Yogyakarta: Program Pascasarjana UNY.

Ponder, J., Veldt, M. V., \& Lewis-Ferrell, G. (2011). Citzenship, curriculum, and critical thinking beyond the four walls of the classroom: Linking the academic content with service-Learning. Teacher Education Quarterly, 38(4), 45-68.

Prasetyo, E., Riyadi, E., Abdi, S., Arham, L., \& Imran, I. (2014). Bahan ajar mata kuliah hukum hak asasi manusia. Yogyakarta: PUSHAM UII.

Widoyoko, E. P. (2014). Penilaian hasil pembelajaran di sekolah. Yogyakarta: Pustaka Pelajar

Ranjabar, J. (2014). Dasar-dasar logika, sebuah langkah awal untuk masuk ke berbagai disiplin ilmu dan pengetahuan. Bandung, Alfabeta

Republik Indonesia. (2003). Undang-Undang RI Nomor 20 Tahun 2003, tentang Sistem Pendidikan Nasional.

Santiago, H.C. (2011). Visual mapping to enhance learning and critical thinking skills. Optometric education journal, Volume 36, Number 3/Summer 2011.

Santrock, J.W. (2014). Psikologi pendidikan, educational psychology. Edisi 5, buku 2 . (Terjemahan Harya Bhimasena) Texas, Mc.Graw-Hill

Schraw, G. \& Daniel, R.R. (Eds.). (2011). Assessment of higher order thinking skills. IAP-Information Age Publishing, Inc.

Sedlak, C. A., Doheny, M. O., Panthofer, N., \& Anaya, E. (2003). Critical thinking in students' service-learning experiences. College Teaching, 51(3), 99-104.

SMA Kolese De Britto. (2015). Student hand book JB 2015. Yoyakarta, SMA Kolese De Britto

Soleimani, H., \& Nabizadeh, F. (2012). The effect of learner constructed, fill in the map concept map technique, and summarizing strategy on Iranian preuniversity students' reading comprehension. English Language Teaching, 5(9), 78-87.

Spears, L. C. (2005). The understanding and practice of servant leadership.
International Journal of Servant Leadership, 1(1), 29-46.

Stein, B. S., Haynes, A. F., \& Unterstein, J. (2003, December). Assessing critical thinking skills. In SACS/COC Annual Meeting, Nashville TN.

Stobaugh, R. (2013). Assessing critical thinking in middle and high schools: Meeting the Common Core. Routledge.

Subali, B., \& Suyata, P. (2012). Pengembangan item tes konvergen dan divergen. Yogyakarta: Diandra Pustaka Indonesia.

Subali, B. (2012). Prinsip asesmen \& evaluasi pembelajaran. Yogyakarta, UNY Press.

Subiyanto. (1988). Evaluasi pendidikan ilmu pengetahuan alam. Jakarta: Proyek Pengembangan Lembaga Pendidikan Tenaga Kependidikan.

Sudjana, S. (1980). Disain dan analisis eksperimen. Bandung: Tarsito.

Sugiyono, S. (2014). Metode penelitian pendidikan: Pendekatan kuantitatif, kualitatif, dan $R \& D$. Bandung: Alfabeta.

Surya, M. (2015). Strategi kognitif dalam proses pembelajaran. Bandung: Alfabeta.

Suryadarma, IGP. (2014a). Uniquiness of Indonesian indigenous knowledge to develop awarness of environmental education. International Congress for School Effectiveness and Improvement.

Suryadarma, IGP. (2014b). Developing productive education through collaborative approach, A case study in Gajah Wong River management, Yogyakarta. International Congress for School Effectiveness and Improvement.

The Partnership for 21st Century Skills. (2011). P21 common core toolkit, A guide to aligning the common core state standards with the framework for 21 st century skills. Washington, DC: The Partnership for 21st Century Skills.

Thomas, J. W. (2000). A review of research on project-based learning. Retrived from: www.newtechnetwork.org/sites/default/fil es/news/pbl_research2.pdf.

Thomas, A., \& Thorne, G. (2009). How to increase higher order thinking. Retrived from: http://www.cdl.org/articles/how-toincrease-high-orderthinking/

White, L. M., Beck, M. M., Birrenkott, G., Skewes, P. A., \& Layfield, K. D. (2015). 


\section{Jurnal Inovasi Pendidikan IPA, 4 (1), 2018 - 127}

Robertus Arifin Nugroho, I Gusti Putu Suryadarma

Demographic predictors of critical thinking ability in undergraduate animal science students. NACTA Journal, 59(1), 49.

Wilgis, M., \& McConnell, J. (2008). Concept mapping: An educational strategy to improve graduate nurses' critical thinking skills during a hospital orientation program. The journal of continuing education in Nursing, 39(3), 119-126.

Wong, G. (2012). Meaningful GP learning with concept mapping. Education for Primary Care, 23(4), 300-307.

Yusuf, M. (2015). Asesmen dan evaluasi pendidikan. Jakarta: Prenadamedia Group. 